\title{
The Secretariat on Responsible Conduct of Research: Ethics Guardians or Keystone Cops?*
}

\author{
John Lowman \\ School of Criminology, Simon Fraser University, Burnaby, Canada \\ Email: lowman@sfu.ca
}

How to cite this paper: Lowman, J. (2021). The Secretariat on Responsible Conduct of Research: Ethics Guardians or Keystone Cops? Beijing Law Review, 12, 768-793. https://doi.org/10.4236/blr.2021.123041

Received: April 19, 2021

Accepted: August 3, 2021

Published: August 6, 2021

Copyright ( 2021 by author(s) and Scientific Research Publishing Inc. This work is licensed under the Creative Commons Attribution International License (CC BY 4.0).

http://creativecommons.org/licenses/by/4.0/

\section{(c) (i) Open Access}

\begin{abstract}
Human research ethics policies invariably hold confidentiality to be a core ethics principle. However, in North America over the past 50 years, numerous third parties-including police, grand juries, Congressional committees, coroners and corporations-have used various lawful mechanisms, such as subpoenas or search warrants, to attempt to gain access to confidential research information. The failure to legislate confidentiality protection for research participants in Canada may reflect the fact that there have been relatively few lawful threats to research confidentiality. However, the legal landscape has changed significantly over the past seven years; from 2012 to 2018, there were six new third-party party attempts to access confidential research information in criminal, civil and coroners' courts. One of these challenges involved assisted suicide researcher Russel Ogden. In May 2014, the BC Coroner served Ogden, then a Kwantlen faculty member, a summons to interview him under oath concerning the death in 2012 of one of his research participants. Because the Coroner's examination could potentially compromise Ogden's promise of research confidentiality, he requested that Kwantlen provide legal support. When Kwantlen declined to provide that support, a third party made a formal complaint to the Secretariat on Responsible Conduct in Research concerning Kwantlen's conduct. The ensuing article describes the Secretariat response to that complaint. The article suggests that, rather than leaving the defence of research confidentiality in the courtroom to individual research institutions, the Granting Councils should establish a fund to which universities contribute to defend research confidentiality against any lawful challenge.
\end{abstract}

\section{Keywords}

Research Confidentiality, Court Challenges to Research Confidentiality, Assisted Suicide Research

${ }^{\star}$ Thanks to Arthur Fallick and Russel Ogden for their comments on a draft of this paper. 


\section{Background}

Every human research ethics policy I have ever seen acknowledges the indispensable importance of confidentiality to research with humans, especially when it involves illegal or disreputable conduct or physical and psychological health. However, in North America over the past 50 years, numerous third parties-including police, grand juries, Congressional committees, coroners and corporations-have used various lawful mechanisms, such as subpoenas or search warrants, to attempt to gain access to confidential research information. In so doing, they have mounted a substantial threat to the academic freedom of researchers to conduct independent research.

Such has been the threat in the U.S., where there have been dozens of such challenges to research confidentiality, that state and federal legislators have enacted various shield laws to protect confidential research information from compelled disclosure ${ }^{1}$. In Canada, there are no research shield laws apart from a component of the Statistics Act, which protects participants in Statistics Canada research.

The failure to legislate confidentiality protection for all but Statistics Canada research participants may reflect the fact that, by comparison to the US, there have been relatively few attempts by third parties to use lawful means to obtain confidential research information. However, the Canadian research confidentiality legal landscape has changed dramatically over the past seven years. From 2012 to 2018, there were six new third-party party attempts to access confidential research information in criminal, civil and coroners' courts-on average, one every fourteen months (Palys and Lowman, 2019). Had any one of these been successful, it could have cast a damp chill on the entire human research enterprise in Canada. The ensuing article describes what happened when a researcher from one research institution-Kwantlen Polytechnic University-was summonsed to appear at a Coroner's Court.

The article concludes by suggesting that, rather than leaving the defence of research confidentiality in the courtroom to individual institutions, the Granting Councils establish a fund to which universities contribute according to the amount of their research funding. The Councils would use this fund to defend research confidentiality against any potential lawful challenge.

\section{Research Ethics Regulation in Canada: Who Is Responsible for Defending Research Confidentiality in Court?}

As the formal policy statement of Canada's three research-funding agencies(CIHR, NSERC and SSHRC ${ }^{2}$ )—the Tri-Council Policy Statement on Responsible

\footnotetext{
${ }^{1}$ At the federal level, the most noteworthy of these are the privacy certificates that protect federally funded criminal justice research and confidentiality certificates that protect health research (Palys, Turk and Lowman, 2018).

${ }^{2}$ Canadian Institutes of Health Research (CIHR), the Natural Science and Engineering Research Council (NSERC) and the Social Sciences and Humanities Research Council (SSHRC).
} 
Conduct in Research lays out the principles by which academics perform research on humans in Canada. At the heart of that protection is the researcher's duty to protect the confidentiality and/or anonymity of research participants:

"Fulfilling the ethical duty of confidentiality is essential to the trust relationship between researcher and participant, and to the integrity of the research project." Tri-council policy statement. Ethical conduct for research involving humans (CIHR, NSERC and SSHRC, 2014: p. 58)

However, as much as confidentiality is essential to certain kinds of research:

"[Sometimes] a third party may seek access to information obtained and/or created in confidence in a research context, or may seek to compel disclosure through force of law (e.g., by subpoena)." (CIHR, NSERC and SSHRC, 2014: p. 60)

In the event that a researcher should experience a lawful challenge to research confidentiality, the funding agencies assert that:

"Institutions shall support their researchers in maintaining promises of confidentiality." (CIHR, NSERC and SSHRC, 2014: Article 5.1)

"When there is a conflict between researchers' ethical and legal obligations," the Inter Agency Panel on Research Ethics-the federal body responsible for interpreting the Tri-Council Policy Statement-is unequivocal:

"[I]nstitutions must provide financial and other support for researchers to obtain independent legal advice or ensure that such support is provided. Institutions should establish a policy that explains how they will provide that support." (Inter Agency Panel on Research Ethics interpretation of TCSP2 Article 5.1)

These clauses of TCPS2 imply that, in the face of challenges to research confidentiality, most research institutions have performed poorly (Palys and Lowman, 2019). Why else would the guardians of research ethics in Canada-the Secretariat for Responsible Conduct in Research and Interagency Panel on Research Ethics-feel the need to build into TCPS2 an article requiring institutions to fund the legal defence of confidentiality against third party challenges? It implies that university administrators have forgotten that research is one of the academy's primary missions. When confronted with legal threats to REB authorized research, the majority of University administrators have attempted to displace the cost of the legal defence of confidentiality onto faculty and graduate researchers, most of whom do not have the resources to shoulder it. Most administrators, it seems, would like to urge researchers to inform research participants of limits to confidentiality, thereby effectively transferring liability to them. Caveat emptor: we warned you about the limits to confidentiality, so do not expect the institution to defend research confidentiality in court.

Research participants deserve better protection than this. The funding agen- 
cies do not seem to appreciate the burden they have placed on small institutions. In an anonymous survey of research ethics boards across Canada, Palys and Ivers noted that:

"Resource issues in small institutions hinder policy development. Some institutions were taken aback by the PRE 5.1 requirement that they potentially spend hundreds of thousands of dollars defending research." (Palys and Ivers, 2018)

One can appreciate the institutional point of view. Contesting a subpoena or search warrant all the way to the Supreme Court of Canada could easily incur legal expenses approaching seven figures ${ }^{3}$. If any challenge to confidentiality, if successful, would cast a chill on all research, why do the Funding Agencies expect individual institutions to shoulder the full cost of legal proceedings in the name of benefitting the collective? Why is it that Canada's Funding Agencies have not established a contingency fund to which every research institution contributes in proportion to its size to protect research confidentiality in court rather than leaving it to individual institutions? Many of these are primarily teaching institutions with a relatively minor involvement in research.

That the Funding Agencies have not set up such a centralized mechanism for defending research confidentiality or initiated a campaign for the development of a research shield law in Canada, may help to explain the strategy that one university devised to displace onto a researcher who was studying assisted suicide its institutional responsibility to fund the defence of research confidentiality.

The researcher in question, Russel Ogden, was studying assisted suicide while Kwantlen Polytechnic University (KPU) employed him as a faculty member. Because he believed that he conducted his research under the auspices of KPU, he reasoned that KPU was responsible for ensuring the ethical probity of his work as the TCPS requires. Consequently, he submitted all of his research proposals to the Kwantlen Research Ethics Board (REB) for review. The KPU REB authorized the research that is the subject of the ensuing article.

In the process of overseeing Ogden's research, KPU not only violated TCPS2 Article 5.1 but also disregarded the Tri-Agency Framework. Responsible Conduct of Research (TAFRCR). The TAFRCR holds that one of the responsibilities of research institutions is to "strive to provide an environment that ... fosters researchers' abilities to act honestly, accountably, openly and fairly in the search for, and dissemination of, knowledge" (section 4.2). In the case of the research the ensuing article describes, KPU blatantly disregarded the principles of openness and transparency.

Indeed, KPU deliberately attempted to thwart its responsibilities under TCPS2 and TAFRCR, which it violated in the process. Worse still, the Presidents of

${ }^{3}$ When Montreal Police seized a confidential research interview conducted for a study of escort-service sex work by University of Ottawa ( $\mathrm{U}$ of O) Profs Chris Bruckert and Colette Parent, their legal fees came to roughly $\$ 300,000$ without involving any kind of appeal. Initially, the Canadian Association of University Teachers (CAUT) covered those costs when $\mathrm{U}$ of $\mathrm{O}$ refused to do so. Subsequently, U of O covered half the fees (Palys and Lowman, 2019). 
Canada's three Funding Agencies ignored several key elements of a formal complaint a third party (me) made about these infractions. By doing so, the Presidents' conduct raises unsettling questions about the ability of the Secretariat for Responsible Conduct in Research to hold to account institutions that perpetrate serious infractions of Canada's national research ethics codes and related policies. In this instance, the three Funding Agency presidents appear to have rubber-stamped the Secretariat's recommendations without consulting the evidence presented in the third party's complaint. Indeed, in its letter to Kwantlen outlining the findings of the Secretariat's investigation, the Presidents do not even mention several key components of that complaint.

The exposé begins with a brief description of the factors that led TCPS2 to include the requirement that institutions fund independent legal representation for researchers defending research-participant confidentiality in court or other legal proceedings. The story starts with Russel Ogden's research on assisted suicide and euthanasia (Ogden, 1994). The participants in his criminology Masters Degree research at Simon Fraser University (SFU) were the first in Canada, as far as I know, to experience a lawful threat to a researcher's guarantee of confidentiality. The controversy surrounding Ogden's research and SFU's refusal to fund the defence of Ogden's research participants at a coroner's inquest (Lowman and Palys, 2001; Palys and Lowman, 2014) together with the realization that there had been dozens of such challenges in the US since 1970 appear to have provided the impetus for the inclusion of Article 5.1 in TCPS2.

At the inquest, Ogden informed the coroner he was prepared to provide any information the coroner wanted, except information that would identify his research participants, to whom he had given a pledge of absolute confidentiality. Realizing the threat that the coroner's subpoena represented to academic research more generally, Ogden retained legal counsel.

Ogden's counsel successfully employed the common law Wigmore test ${ }^{4}$, which the Supreme Court of Canada has recognized as the most appropriate way to evaluate claims of evidentiary privilege, to defend his pledge of confidentiality. However, initially, SFU contributed just $\$ 2000$ on "compassionate grounds" towards Ogden's legal fee of $\$ 11,367.38$, arguing that it was not contractually bound to cover that fee ${ }^{5}$.

Out of pocket, incredulous that SFU had abandoned his research participants ${ }^{4}$ The Wigmore test comprises four components that a communication must pass in order to be privileged: 1) The communications must originate in a confidence that they will not be disclosed. 2) This element of confidentiality must be essential to the full and satisfactory maintenance of the relation between the parties. 3) The relation must be one which in the opinion of the community ought to be sedulously fostered. 4) The injury to the relationship that disclosure of the communications would cause must be greater than the benefit gained for the correct disposal of the litigation (Wigmore, 1905). A treatise on the system of evidence in trials at common law, including the statutes and judicial decisions of all jurisdictions of the United States, England, and Canada. Boston: Little, Brown and Company.

${ }^{5}$ After an internal inquiry in response to a campaign to secure justice for Ogden and his research participants (Blomley and Davis, 1998), SFU acknowledged that it had been wrong to abandon Ogden's research participants in court. SFU apologized, reimbursed the full amount of Ogden's legal fees and compensated him for three months of wages lost to his fight to hold SFU to account. 
and aware of the implications of SFU's liability approach for research participants in Canada more generally, Ogden attempted to recover his legal fees. $\mathrm{He}$ sued SFU in Small Claims Court for the balance, which came to just under $\$ 10,000$, on the ground that SFU was contractually obliged to cover those fees. One consequence of his use of law to speak truth to power was that it gave him the authority to subpoena the principal SFU administrators involved in the decision to abandon his research participants in Coroner's Court. The ensuing testimony of both SFU's President and Vice-President Research revealed that they based their decision to abandon Ogden on considerations of liability and impression management-they did not want anyone to perceive SFU as supporting assisted suicide-rather than the ethical imperative of maintaining the anonymity of his research participants.

Sadly, it would not be the last time that Canadian university administrators suffered amnesia when researchers approached them for funds to contest a lawful threat to research confidentiality.

\section{Ogden's Assisted Suicide Research at Exeter University}

In 1996, Ogden enrolled in the Sociology Doctoral program at Exeter University. Mindful of his experience at SFU when the administration abrogated its responsibility to defend research confidentiality in Coroner's court, Ogden wanted to know from the outset if Exeter would protect his research participants in the event that he was to receive another subpoena. After all, the informed consent of his research participants depended on such information, as they would feel much more confident participating knowing that the university would support them in court rather than displacing this responsibility to a graduate student with a meager income.

Initially, the ethics committee overseeing Ogden's research provided him with a letter saying that Exeter would provide legal assistance if needed. However, when a conflict with his supervisor arose and Ogden received a copy of his university file, he realized that someone on the ethics committee had changed the letter by removing the clause about university support. As a result, Ogden could no longer use the interviews he had already conducted, as his informed consent statement had unwittingly misinformed his research participants that such support would be forthcoming if necessary (Lowman and Palys, 2014). As at SFU, university administrators had lost sight of the university's role-one subsequently enshrined in Canada's national research ethics guidelines-should there be a courtroom challenge to research confidentiality.

\section{Ogden Continues His Assisted Suicide Research at Kwantlen University College}

In 1999, while Ogden was pursuing still his Doctoral research at Exeter, Kwantlen University College (hereafter "Kwantlen"6) employed him as a sessional in-

${ }^{6}$ In 2008, its name changed to Kwantlen Polytechnic University. 
structor. In 2004, he became a fulltime Criminology and Sociology faculty member. Still intent on earning a $\mathrm{PhD}$, Ogden continued his research on suicide and assisted suicide as a Kwantlen employee. He submitted all his research proposals to the Kwantlen REB. He thus conducted his research "under the auspices of Kwantlen” as defined by Kwantlen's research ethics policy (G27).

Twice while he was conducting assisted suicide research-first in 2003, and again in 2004-a Crown prosecutor subpoenaed Ogden in relation to the trial of Ms Evelyn Martens, which Ogden was observing as part of his research (Palys and Lowman, 2010; Ogden, 2014). The Crown had charged Martens with aiding and abetting a suicide. It turns out that both subpoenas were fishing expeditions, an abuse of power; the Crown issued them to find out if Ogden had information that was relevant to the prosecution of Martens ${ }^{7}$. On both occasions, when it became clear that Ogden would vigorously resist a subpoena-and in the case of the 2004 subpoena, so would Kwantlen-the Crown prosecutor withdrew it. These events together with Ogden's experience at SFU and Exeter made Kwantlen administrators aware that protecting research confidentiality may come at a cost. To them, that cost must have seemed almost inevitable in research on assisted suicide. Worse still, the researcher had shown himself to be someone who would not rest until he had exhausted every legal means available to hold delinquent institutions to account. After the fiascos at SFU and Exeter, how would Kwantlen fare?

Not well, it turns out.

\subsection{Kwantlen Oversees Ogden's Research}

On 12 July 2005, the Kwantlen REB approved Ogden's proposal to attend assisted suicides and "NuTech" deaths. Ogden's original proposal was to attend a single death, but after a lengthy exchange with Ogden and a scholarly review of his research proposal, the REB expanded its approval to include multiple deaths. The Kwantlen REB issued an ethics certificate that had no expiry date.

On December 11, 2006, seventeen months after receiving REB approval, the Kwantlen administration summoned Ogden to a meeting at which the Provost/VP-Academic told him, "you are not to engage in any illegal activity including attending at an assisted death" (Ogden, 2014). This "stop-research edict", which the Kwantlen administration issued prior to seeking a legal opinion as to whether it was correct, apparently is the first time a Canadian university has ordered a researcher to stop REB-approved research. However, if the research did not involve a criminal offence, stopping it violated Ogden's academic freedom to conduct research, thereby drawing the attention of outside parties, including the Canadian Association of University Teachers (CAUT).

\subsection{Liability and Controversy Issues}

The stop-research edict indicates that the Kwantlen administration thought that,

${ }^{7}$ To justify issuing a subpoena the Crown has to have reason to believe that Ogden had material evidence pertaining to the prosecution. 
by attending a suicide, Ogden would commit the criminal offence of aiding and abetting a suicide. Controversy had surrounded Ogden's MA research on euthanasia and assisted suicide at SFU and his Doctoral research at Exeter. Both had to compensate him for their failings. While Ogden was a faculty member at Kwantlen conducting research under its auspices, Crown Counsel had already issued him two subpoenas to attend the trial of Evelyn Martens.

From the Kwantlen administration's perspective, Ogden's research on assisted suicide was the perfect storm.

After issuing the stop research edict, Kwantlen sought an ex post facto justification by acquiring a formal legal opinion. L. Doust Q. C. provided that opinion. Doust concluded that, by attending a suicide, Ogden would indeed commit a criminal offence. Surprisingly though, Doust's opinion did not cite the assisted suicide case law or prosecution guidelines on when to lay charges for aiding and abetting a suicide. Nor did it analyze Ogden's carefully crafted research protocol, which is hardly surprising given that Kwantlen neglected to provide him with a copy.

Because of the implications of stop research edict for academic freedom, CAUT commissioned an independent legal opinion from E. David Crossin Q. C. ${ }^{8}$. When Crossin scrutinized Ogden's research protocol and the relevant case law, he concluded that, if Ogden attended a suicide using the research protocol the Kwantlen REB had approved, his attendance would be unlikely to constitute a criminal offence. In light of that opinion, CAUT initiated an investigation into Kwantlen's apparent infringement of Ogden's academic freedom to conduct research.

At that juncture, Kwantlen capitulated and allowed Ogden to continue his research.

On 19 November 2008, Kwantlen President David Atkinson sent a memo to members of the Sociology and Criminology departments announcing that Kwantlen and the Kwantlen Faculty Association (KFA):

...have reached a settlement agreement on the issue of Russel's Academic Freedom as it relates to his research. While details of the agreement are confidential, the parties to the agreement are pleased with the resolution. Russel will commence a research leave on January 1, 2009 and return January $1,2011$.

Following this news, CAUT terminated its investigation. While on leave, Ogden proceeded with his research on suicide and assisted suicide as per the REB's July 12, 2005 approval.

After Ogden returned from his two-year research leave, BC's public employee database indicates that Kwantlen continued to pay his full-time salary until December 31, 2015. However, throughout this five-year period, Kwantlen's website described Ogden as being "on leave". From January 1, 2011 to December 31, 
2015, he performed no teaching or administrative duties. His sole "accountable time" activity-i.e. that for which Kwantlen paid him as a faculty member-was research.

Ogden retired on December 31, 2015.

\section{Another Coroner's Subpoena and an Alleged Violation of TCPS2 Article 5.1}

In May 2014, while Ogden was still a Kwantlen faculty member, the BC Coroner served him a summons to interview him under oath concerning the death in 2012 of one of his research participants. Ogden complied and attended the Coroner's office in Burnaby at the designated time: 9.30 am on November 13, 2014. Because the Coroner's examination could potentially compromise the promise of confidentiality that Ogden gave his research participants, he requested that Kwantlen provide legal support.

Given Prof Palys' and my prior involvement in bringing Kwantlen's violation of its responsibilities under TCPS2 and its Memorandum of Understanding with the granting agencies ${ }^{9}$, we wrote to President Alan Davis concerning Kwantlen's responsibilities under TCPS2 Article 5.1 (letter dated November 1, 2014). Our letter quoted the 2014 Interagency Panel on Research Ethics interpretation of Article 5.1 that:

When there is a conflict between researchers' ethical and legal obligations, institutions must provide financial and other support for researchers to obtain independent legal advice or ensure that such support is provided. Institutions should establish a policy that explains how they will provide that support ${ }^{10}$ (emphasis added).

According to PRE's interpretation, if Ogden was conducting research under Kwantlen's auspices, Kwantlen must provide support once the Coroner threatened the confidentiality of any of his research participants.

However, when I attended the Coroner's office on 13 November 2014 to observe the hearing, Kwantlen did not send a lawyer or any other representative to support Ogden.

\subsection{Kwantlen Discloses a "Private and Confidential Agreement"}

On November 24 2014, Palys and I received President Davis' response to our letter concerning Kwantlen's responsibilities under TCSP2. President Davis asserted that:

${ }^{9} \mathrm{Kwantlen}$ failed to ensure that more-than-minimal-risk research carried out under its auspices received REB review and oversight. In this instance, three Kwantlen researchers failed to apply for REB review of a more-than-minimal-risk study of indigenous youth on Vancouver's Downtown Eastside. However, contrary to the requirements of its MOU with the funding Agencies, Kwantlen did not have a "Misconduct in Research" policy that would allow anyone to make a complaint about the actions of the three researchers. Instead, Kwantlen had to establish an ad hoc inquiry to investigate a complaint we made against them (Lowman and Palys, 2014).

${ }^{10} \mathrm{https}$ ://ethics.gc.ca/eng/policy-politique_interpretations_privacy-privee.html (accessed February $11,2020)$. 
Kwantlen Polytechnic University is committed to providing support for its researchers, consistent with the Tri-Council Policy Statement referred to in your letter. See KPU's Research Involving Human Participants Policy, and Principles of Academic Freedom, which are available on our website at: https://www.kpu.ca/policies/.

The issues raised in your letter regarding Russel Ogden are governed by a private and confidential agreement reached between KPU, Mr. Ogden and the Kwantlen Faculty Association. The agreement contains a mechanism for the resolution of any disputes by an independent arbitrator. Mr. Ogden and/or the KFA may access this dispute mechanism if they believe KPU has not lived up to its obligations under the agreement.

President Davis' response did not address several key issues. For example:

- Given that his predecessor, President Atkinson, informed Kwantlen Criminology and Sociology faculty that Ogden would return from leave on 1 January 2011, what was Ogden's role at Kwantlen from January 1, 2011 through December 31, 2015?

- Why did the four references to Ogden on Kwantlen's 2014 website all list him as being "on leave" ${ }^{11}$ ?

- Did Kwantlen pay Ogden a full-time salary while he was on leave for seven years, starting on January 1, 2009 and ending on September 1, 2015, the date he retired?

- How could Kwantlen use taxpayer dollars to pay Ogden for five years to conduct "independent research", phrasing that indicates Kwantlen's desire to disassociate itself from this research?

President Davis' claim that Ogden could access the dispute mechanism was not borne out by the arbitrator, who in 2014, ruled that only Kwantlen and the KFA could access that mechanism. While the arbitrator may be responsible for dealing with disputes among parties to the Confidential Agreement, whoever they may be, what if a third party wished to raise questions about that Agreement?

Indeed, the purpose of the current article is to raise important public policy issues about the Confidential Agreement, including Kwantlen's compliance with TCPS2 and the Tri-Agency Framework: Responsible Conduct of Research (TAFRCR). Presumably, the Confidential Agreement cannot trump the national research ethics policies to which Kwantlen is subject. However, when I submitted a complaint to the Secretariat on Responsible Conduct in Research that Kwantlen had violated TCPS2 Article 5.1, Kwantlen refused to provide a copy of the Agreement to the Secretariat even though it clearly deals with Ogden's research.

That left me wondering what action the Presidents of CIHR, NSERC and SSHRC would take against Kwantlen for having made an agreement that disregards the interests of public policy in holding institutions accountable to the ethics codes that are supposed to control their practices. Surely, the Confidential

${ }^{11}$ This entry on Kwantlen's website has since been removed. 
Agreement is itself a prima facie violation of the TAFRCR Article 4.2. Although the Confidential Agreement predated the TAFRCR by a few months, surely Kwantlen's refusal to disclose any of the details of the Confidential Agreement after Ogden gave his permission to disclose it was a violation of Article 4.2 once it had come into effect.

\subsection{A Prima Facie Violation of TAFRCR Article 4.2}

Under the TAFRCR, one of the responsibilities of research institutions is to: ...strive to provide an environment that ... fosters researchers' abilities to act honestly, accountably, openly and fairly in the search for, and dissemination of, knowledge (TAFRCR, Section 4.2).

On October 16, 2014, Kwantlen geographer and KFA Executive member Dr. Bill Burgess posted a comment about Kwantlen's proposed "Respectful Workplace Policy" in relation to a threatened libel suit involving four Kwantlen faculty members in 2007. One Kwantlen researcher brought the suit against Ogden and two colleagues when they accused that researcher of conducting research under Kwantlen's auspices without REB approval (Lowman and Palys, 2014). However, Kwantlen surreptitiously funded the threatened libel suit, not the researcher. Burgess referred to the circumstances surrounding the suit as the "Ogden case":

... the KPU administration has made it impossible for any serious airing of the issues in the "Ogden case" to occur. Instead, we have the bizarre situation where Ogden has for years now been a paid full-time faculty member but teaches no course for KPU and seems to be banned from physically attending any KPU campus. Questions to university officials about Ogden yield non-responses.

What kind of a respectful workplace "disappears" people this way? What does that say about the atmosphere or environment of this workplace that another colleague who was involved in this case told me, "I feel there is a target on my back"?

Burgess has since reported that, at a subsequent meeting with Dr. Harry Gray, Kwantlen's Associate Vice President Human Resources ${ }^{12}$, when asked if Ogden was a Kwantlen employee, Gray said "yes". However, when asked if Ogden had to submit his research to the Kwantlen REB, Gray said "no", thus making it appear that Ogden conducted his research at Kwantlen without REB review and oversight.

A 2012 article in the Toronto Star (Cribb, 2012) confirmed the information that Gray disclosed to Burgess. The Star reported Ogden as saying that he had not taught any courses at Kwantlen since 2008, and that he missed teaching: "not doing it is challenging to the identity of a university instructor". The article reported that Ogden was "included in B.C. public salary disclosure list as having ${ }^{12}$ Kwantlen Faculty Association Vice-President Bob Davis also attended this meeting. 
earned just over \$85,000 last year" and quoted an unnamed "Kwantlen spokesperson" as saying that "the professor is conducting independent research". In 2013, British Columbia's salary disclosure list revealed that Kwantlen employed Ogden that year for a salary of $\$ 85,283.00$.

The inescapable conclusion is that Kwantlen used taxpayers' funds to pay Ogden for five years to conduct "independent research", whatever that may be. What alternative interpretation is there?

\subsection{Kwantlen Employed Ogden Full Time to Conduct "Independent Research"}

On October 29, 2014 Kwantlen criminologist Dr. Greg Jenion wrote to Kwantlen REB Chair Dr. Kyle Matsuba asking:

How do researchers and the ethics board determine what research is independent and what research is not and requires ethics review? What are the conditions I must meet to do research with human subjects as a full time faculty member and avoid REB review?

On November 14, 2014, Matsuba replied:

I have been trying, unsuccessfully, to get a response from senior administration regarding the employment status of Russel Ogden. I have yet to receive a response from the university regarding Mr. Ogden's employment status. If he is employed by the university, then many of the questions you have posed will need to be addressed.

Matsuba's response indicates that the REB did not oversee Ogden's research why else would he need to ask the administration if Kwantlen still employed Ogden? If the Chair of the Kwantlen REB cannot get a response from the administration in these circumstances, it is difficult to see how Kwantlen was striving "to provide an environment that ... fosters researchers' abilities to act honestly, accountably, openly and fairly in the search for, and dissemination of knowledge" (TAFRCR Section 4.2). With the confidential agreement hanging over his head like Damocles' sword, how could Ogden act "accountably, openly and fairly" in conducting his research?

Can Kwantlen employ a researcher fulltime, but under its own policies exempt her/him from REB oversight, as Gray asserted? No, it cannot. Kwantlen's research ethics policy $\left(\mathrm{AD} 093^{13}\right)$ clearly defines its ambit:

This Policy applies to all research involving human participants conducted under the auspices of Kwantlen Polytechnic University ("Kwantlen"). Research conducted under the auspices of Kwantlen includes, but is not limited to, research where funds are provided through or administered by Kwantlen; research where the researcher's affiliation with Kwantlen is explicit in contracts, reports or publications; research which utilizes Kwantlen

${ }^{13} \underline{\text { http://www.kpu.ca/sites/default/files/Research/research_involving_human_participants_policy_g2 }}$ 722263.pdf (accessed February 11, 2020). 
resources (including accountable and professional development time); and research conducted by Kwantlen students as a component of their course or program requirements (Emphasis added).

According to this policy, if research utilizes any of an employee's contractual "accountable time", that employee must submit her/his research to the REB for review and oversight. If Kwantlen employed Ogden to conduct research as his only duty, it was "independent" in name only.

Given that Ogden conducted the research under Kwantlen's auspices, TCPS2 Article 2.1 obliged Kwantlen to ensure that the REB oversaw the research and reviewed it annually. TCPS2 Article 5.1 obliged Kwantlen to support Ogden when the Coroner summonsed him for an examination into the death of one of his research participants. Kwantlen did not provide that support. By violating TCPS2 Articles 2.1 and 5.1, Kwantlen failed to comply with its Agreement on the Administration of Agency Grants and Awards by Research Institutions.

\section{A Complaint to the Secretariat on Responsible Conduct in Research}

In view of the difficult situation the Confidential Agreement placed Ogden and because of its broader implications for how universities manage the ethics of controversial social research, Palys and I decided to submit a complaint to the Secretariat on Responsible Conduct of Research (hereafter, the Secretariat). As Palys had submitted an earlier complaint against the University of Ottawa when it, too, failed to support researchers defending confidentiality in court, I submitted the complaint about Kwantlen to the Secretariat's $\mathrm{CEO}^{14}$. I based the complaint on the evidence about Ogden's employment presented above.

My December 10, 2014 complaint comprised three elements:

1) Kwantlen did not comply with TCPS2 Article 2.1, which, in the case of research involving living human participants, "requires ethics review and approval by an REB before the research commences".

2) Kwantlen did not comply with TCPS2 Article 5.1, which holds that, “... Institutions shall support their researchers in maintaining promises of confidentiality".

3) Kwantlen did not comply with the Tri-Agency Framework. Responsible Conduct of Research, (the Tri-Agency Framework) which holds that one of the responsibilities of research institutions is to "strive to provide an environment that ... fosters researchers' abilities to act honestly, accountably, openly and fairly in the search for, and dissemination of knowledge" (Tri-Agency Framework, Section 4.2).

Ultimately, it took over four years for the Secretariat to process the complaint and for SSHRC to communicate the decision to Kwantlen. During that period, Ogden submitted an access to information request for disclosure of the Secreta${ }^{14}$ I copied the complaint to Kwantlen President Alan Davis, Ogden, the Chair of the Kwantlen REB, and Kwantlen faculty members Bill Burgess and Greg Jenion, both of whom had given me permission to include their comments in the complaint (I copied to Ogden all correspondence relating to the complaint). 
riat's files pertaining to my complaint. Because of this new information, I added two components to my original complaint, which I sent to the Secretariat on November 12, 2017:

4) Kwantlen did not comply with TCPS2 section 6.14, which requires that the institutional REB must conduct an annual review of all human research conducted under the institution's auspices.

5) Kwantlen violated Section 4.4.a.ii of the Agreement on the Administration of Agency Grants and Awards by Research Institutions, which says that one way an "institutional default" occurs is "If the Institution has submitted materially false or misleading information or has made representations of a material nature to an Agency, other than in good faith".

On July 13, 2018, appalled by the way by the Secretariat was dragging its heels, Ogden also submitted a complaint about Kwantlen's conduct. His complaint asserted that:

1) By claiming that he had access to the arbitration mechanism in the confidential agreement after the arbitrator had ruled that only Kwantlen and the KFA could access the mechanism, Kwantlen gave false and misleading information to the Secretariat contrary to section 4.4.a.ii of the Agreement on Administration of Grants and Awards by Research Institutions.

2) Contrary to TCPS2 Article 5.1, Kwantlen did not support Ogden when the BC Coroner summoned him on November 13, 2014.

3) The confidential agreement inhibited Ogden's capacity to be totally honest and accountable with his research participants. Contrary Article 4.2 of the Tri-Agency Framework, Ogden could not tell participants that Kwantlen disassociated itself from the REB-approved research it assigned him to carry out.

4) By preventing Ogden from submitting annual reports to the REB between 2011 and 2015, and instead requiring a report to the Kwantlen President, Kwantlen acted on a conflict of interest. Although Ogden did not identify the relevant policy, TCPS2 Ch. 7 section II prohibits institutional conflict of interest of this sort, as an institution must carry out ethics review independently of the institution's administration.

5) TCPS2 Article 1.1 spells out the three "core principles" guiding TCPS2, i.e. respect for persons, concern for welfare, and justice. From a participant perspective, the confidential agreement ensured confusion about the auspices under which Ogden conducted his research, particularly if a participant were to complain to Kwantlen about her or his rights.

While the first three of Ogden's complaints repeated Lowman's allegations, his fourth and fifth complaints covered new ground. Taken as a whole, the two complaints asked the Secretariat to investigate allegations of seven distinct Federal policy violations by Kwantlen (Table 1).

\section{The Secretariat's Complaints against Institutions Procedure: What Procedure?}

On December 12, 2014, two days after I submitted my initial complaint, I received 
Table 1. Lowman and Oogden complaints concerning Kwantlen.

\begin{tabular}{lcc}
\hline LOWMAN COMPLAINT & OGDEN COMPLAINT & $\begin{array}{l}\text { PRESIDENTIAL } \\
\text { RESPONSE }\end{array}$ \\
\hline $\begin{array}{l}\text { 1. Kwantlen did not comply with TCPS2 Article 2.1, } \\
\text { which "requires ethics review and approval by an REB } \\
\text { before the research commences." }\end{array}$ & $\begin{array}{l}\text { The confidential } \\
\text { agreement prevented } \\
\text { a determination. }\end{array}$ \\
$\begin{array}{l}\text { 2. Kwantlen did not comply with TCPS2 Article 5.1, } \\
\begin{array}{l}\text { which holds that, "... Institutions shall support their } \\
\text { researchers in maintaining promises of }\end{array}\end{array}$ & $\begin{array}{l}\text { 2. Contrary to TCPS2 Article 5.1, Kwantlen did not support } \\
\text { Ogden when the BC Coroner summoned him on November }\end{array}$ & $\begin{array}{l}\text { The confidential } \\
\text { agreement prevented }\end{array}$ \\
& 13, 2014. & a determination
\end{tabular}

3. Kwantlen did not comply with the Tri-Agency Framework Section 4.2, which holds that research institutions must "strive to provide an environment that ... fosters researchers' abilities to act honestly, accountably, openly and fairly in the search for, and dissemination of knowledge."

4. Kwantlen did not comply with TCPS2 section 6.14, which requires that the institutional REB must conduct an annual review of all human research conducted under the institution's auspices.

5. Kwantlen violated Section 4.4.a.ii of the Agreement on the Administration of Agency Grants and Awards by Research Institutions, which says that one way an "institutional default" occurs is "If the Institution has submitted materially false or misleading information or has made representations of a material nature to an Agency, other than in good faith."

6.

7.
3. The confidential agreement inhibited his capacity to be totally Silence honest and accountable with research participants. Contrary to Article 4.2 of the Tri-Agency Framework, Ogden could not tell participants that Kwantlen disassociated itself from the REB-approved research it assigned him to carry out.

\section{. By claiming that he had access to the arbitration mechanism in the confidential agreement after the arbitrator had ruled Silence that only Kwantlen and the KFA could access the mechanism, Kwantlen gave false and misleading information to the Secretariat contrary to section 4.4.a.ii of the Agreement on Administration of Grants and Awards by Research Institutions.}

4. By preventing Ogden from submitting annual reports to the REB between 2011 and 2015, and instead requiring a report to the Kwantlen President, Kwantlen acted on a conflict of interest. (Although Ogden did not identify the relevant policy, TCPS2 Ch. 7 section II prohibits institutional conflict of interest of this sort, as an institution must carry out ethics review independently of the institution's administration.)

5. TCPS2 Article 1.1 spells out the three "core principles" guiding TCPS2, i.e. respect for persons, concern for welfare, and justice. From a participant perspective, the confidential agreement ensured confusion about the auspices under which Ogden conducted his research, particularly if a participant were to complain to Kwantlen about her or his rights.

an email from a Secretariat Senior Policy Analyst (hereafter the SPA) informing me that she had been assigned my complaint about Kwantlen. In response to my question about what procedure the Secretariat would follow, the SPA replied:

In cases where an allegation is made against an institution rather than an individual, Secretariat staff are usually responsible for the initial phase of the investigation and for assessing whether an external investigator is required (December 12, 2014 email).

Although this response left open the question as to whether the Secretariat would employ the "usual procedure" in this instance, I anticipated that, in the 
name of consistency and fairness, the investigation would at least follow similar timelines to those that the Secretariat imposes on institutions for investigating complaints against researchers, i.e. seven months. However, five months passed and I heard nothing more from the Secretariat. Consequently, on April 24, 2015 I emailed the SPA posing a series of further procedural questions:

What was the result of the initial phase of the investigation?

Was an external investigation deemed necessary and, if it was not, why not? If the Secretariat deemed an investigation necessary, who carried it out, what procedure did they follow, and what did they conclude?

At that point, the SPA elaborated a different procedure, informing me that:

We are following the process set out Section 4 of the Tri-Agency Agreement on the Administration of Agency Grants and Awards by Research Institutions. Section 4 does not have set timelines, but we have commenced our inquiries. (April 30, 2015 email)

Section 4.2 of the Tri-Agency Agreement requires that:

The Institution shall comply with the requirements set out in the Tri-Agency Framework: Responsible Conduct of Research, as amended, which sets out the responsibilities of Institutions, Researchers and Agencies in respect of responsible conduct in research, including the procedures to be followed in the event of a breach of an agency requirement, or an allegation thereof.

According to the Tri-Agency Agreement, the Tri-Agency Framework specifies the Secretariat's procedure for investigating complaints against institutions. However, the Tri-Agency Framework merely says that the Secretariat "will address the allegation in accordance with the Agreement on the Administration of Agency Grants and Awards by Research Institutions". That Agreement goes on to say:

The process followed by the Agencies to address an allegation of a breach of an Agency policy by an Institution, and the recourse that the Agencies may exercise, commensurate with the severity of a confirmed breach, are outlined in the MOU.

The standard MOU between the Granting Agencies and a Research Institution explains that:

...the conflict resolution procedure be used and that the Parties attempt to resolve the matter at the "working level". If a resolution cannot be reached in good faith, the matter should then be brought to the attention of 'the Parties' management for resolution.

This is quite different from the procedure the SPA communicated to me in her December 12, 2014 email, when she asserted that, "Secretariat staff are 
usually responsible for the initial phase of the investigation and for assessing whether an external investigator is required". More curious is that neither of these procedures is consistent with the one described in an internal document that the Secretariat disclosed pursuant to Ogden's access to information request in $2017^{15}$ :

Since this is an allegation against an institution, the internal procedure on allegations against institutions was used, with the Secretariat acting as

"Agency Expert" on matters related to TCPS2.

The SPA also told me that, because of the Secretariat's obligations under Federal privacy law, they would not send me a copy of the report because the outcome "did not directly affect [me]". Indeed, the only commitment the Secretariat made to me about the investigation was that they would inform me once it had completed the investigation, in which case it might not even be possible for me to ascertain the investigation procedure after the fact.

This incoherence combined with the Secretariat's use of privacy law to justify secrecy has made it impossible to figure out what procedure it employed to investigate either my or Ogden's complaints. Compare this to the strict procedures and timelines the Secretariat imposes on institutions for investigating complaints about researcher conduct ${ }^{16}$.

\section{The Secretariat's Do-as-We-Say-Not-as-We-Do Approach to Procedure}

On May 14, 2015, I emailed the SPA proposing revisions of the Tri-Agency Agreement in order to prevent this kind of policy pinball from recurring. The SPA replied that she would forward my proposals to the Granting Agencies, which she did. At the time of writing four years later, however, the Funding Agency Presidents have not responded to my proposals.

\section{The Investigation}

Another year passed without my hearing further from the Secretariat. The investigation, such as it was, had already taken 18 months. Beginning to think that the Secretariat's preference was to drags its heels in the hope that the complaint would die on the vine, I emailed the Secretariat CEO on July 18, 2016, asking when they would complete it. The CEO replied that the file was "ongoing and active" (September 6, 2016 email to the CEO) but said nothing more.

\footnotetext{
${ }^{15}$ Nor was it the procedure Kwantlen proposed in its initial response to the Secretariat after learning of my complaint. Kwantlen's attorney stated that, "Should there be a conflict between any parties to the [Framework] agreement, [Kwantlen] requests that the matter be referred to mediation pursuant to section 4.2 of the Agreement" (letter from Kwantlen's attorney to the Secretariat dated Feb 17, 2015).

${ }^{16}$ "The institution should submit inquiry letters or inquiry reports to the SRCR within two months of receipt of an allegation. If an investigation is warranted, the institution has an additional five months following the end of the inquiry to conduct an investigation and submit its report to the SRCR. The institution therefore has a total of seven months from the date of receipt of an allegation that results in an investigation to report to the SRCR. These timelines may be extended in consultation with the SRCR if circumstances warrant, and with periodic updates provided to the SRCR until the investigation is complete" https://crr.ethique.gc.ca/eng/framework-cadre.html\#a3-1 (accessed February 11, 2020).
} 
In November 2016, Ogden inquired about the status of the investigation. On November 18, 2016, the Secretariat informed him that, "We are in the final stages of our inquiry. We will advise Professor Lowman when it is complete".

Although the investigation had already taken nearly two years and even though it was allegedly in its "final stages", more than another year passed without any further communication from the Secretariat. Frustrated by their tardiness and incoherent procedure, I emailed the Secretariat CEO on November 12, 2017 saying:

...The most recent communication I received from the Secretariat concerning my complaint was on September 6, 2016. On that date, you reported that, "this file is ongoing and active. It is taking longer than I would have liked to bring to resolution. I am hopeful that that will occur in the not too distant future."

That was a year ago. It has been almost three years since I submitted the complaint, and still there is no meaningful indication of when it might be resolved...

By failing to provide any time constraints for the investigation of complaints against institutions, the policy puts complainants in the position of having to nip at the Secretariat's heels lest their complaints die on the vine. Complaint procedures should not encourage these kinds of problems...

Also, I used this opportunity to add two components to my original complaint on the basis of information that came to light following Ogden's ATIP request for records concerning the Secretariat's investigation.

I copied the email to the President of SSHRC, which means the Presidents were aware that I had revised the complaint, a point that will become significant when I comment on their application of the Secretariat's investigation report. After a month passed without a reply, I emailed the CEO asking whether she had received my email with the amended complaint. That same day the CEO replied, "I did receive it", but she said nothing more.

Is this an example of the transparency that is supposed to characterize Secretariat procedures?

Three years had now passed since I submitted my initial complaint about Kwantlen. Fifteen months had passed since the Secretariat CEO told Ogden the inquiry was in its "final stages". Consequently, on February 13, 2018, I again emailed the CEO asking when the investigation would be complete. The following day the CEO replied:

I intend to submit this matter to the Panel on Responsible Conduct of Research at their next meeting, at the end of March. I apologize for what I acknowledge has been an excessive delay.

The end of March came and went without my hearing anything further. On April 26, 2018, I emailed the CEO requesting a copy of the report she sent to the Panel. Again, the Secretariat CEO moved the goal posts: 
We did not present the file to the panel in March. Upon reconsideration, we have decided it would be more appropriate to bring this matter to senior management in accordance with the conflict resolution provision of the Agreement on Administration of Agency Grants and Awards by Research Institutions (s. 5.1) (CEO email to Lowman dated May 4, 2018).

Why did she not inform me of this procedural maneuver? Is this what the Secretariat means by "transparency"?

Seven more months of silence followed.

\subsection{Tri-Agency Agreement Article 5.1 Should Have Timelines for Investigating Institutions}

According to Tri-Agency Agreement Article 5.1:

In the event of a conflict with respect to the Agreement or its implementation, the parties shall first attempt to resolve the conflict at the working level, in good faith. If unsuccessful, the conflict shall be brought to the attention of the parties' management for resolution. The Agency shall, in consultation with the institution, determine an acceptable time line to resolve the conflict. If the parties concerned agree, the matter may be referred to mediation before a mutually acceptable third party (emphasis added).

On the fourth anniversary of my complaint, I emailed the Secretariat CEO asking why it took more than three years to invoke Article 5.1. Under the provisions of Article 5.1, what deadline had Kwantlen and the Secretariat agreed to resolve my complaint? If the deadline had passed, what was the outcome? Why was I, the complainant, kept in the dark about all these procedural issues?

In her response, the CEO denied that it took three years to invoke Article 5.1 of the Tri-Agency Agreement, as the Secretariat had contacted Kwantlen within days of receiving the complaint, which "set off a lengthy process among the relevant parties".

If that is true, why did both Kwantlen and the Secretariat ignore the requirement that the Agency and Institution "determine an acceptable time line to resolve the conflict"?

\subsection{The Secretariat's Explanation for the Causes of the Delay}

While the CEO acknowledged that there was good reason to be concerned at the length of time it had taken to resolve the Kwantlen complaint, she asserted that this case was not representative of the time it takes for the Secretariat to resolve most complaints. In her eyes, two factors explained the anomaly: First, the Secretariat's criteria for prioritizing complaint investigations given its scarce resources. Second, the problems the confidential agreement posed the investigation.

As to the first factor, the CEO noted:

Given the volume of allegations the Secretariat receives (roughly 50 active files at any given time) decisions must be made about how to allocate hu- 
man resources. Not surprisingly, we give priority to files affecting active researchers and active grants.

If that really is the case, then surely Ogden's research should have received a high priority. To begin with, if the Secretariat had followed the timelines for investigation of complaints against researchers, even allowing for a five-month extension, they would have completed it while Ogden was an "active researcher". Further, his research participants were persons who police could have charged with murder or aiding and abetting a suicide. He had to pay $\$ 22,806$ for legal representation at the Coroner's hearing, a considerable investment for a person who Kwantlen and the KFA had cornered into early retirement, who had only a modest university pension, no job and was not old enough to collect Canada Pension Plan payments or Canada Old Age Pension. Yet pay that fee he did.

Of the 50 complaints that the Secretariat was dealing with at any given moment, the vast majority involved researchers, not institutions. In addition to Ogden's research fulfilling the criteria the CEO identified, what other criteria might be relevant? For example, what would the Secretariat's priority be if one of the funding agencies had previously disciplined a researcher or institution for ethics code violations ${ }^{17}$ ?

Kwantlen's previous misconduct was sufficiently serious that the Funding Agencies intervened. Add Kwantlen's recidivism to the fact that Ogden's research was active when I made the initial complaint, then surely the Secretariat should have given my Kwantlen complaint the highest priority for investigation.

As to the second factor, the confidential agreement, Kwantlen refused to disclose it to the Secretariat on the ground that, "The University could only disclose the [terms of the confidential agreement] if it were required to do so by an order of court of competent jurisdiction or by law" (February 17, 2015, letter from Kwantlen's attorney to the Secretariat). Kwantlen argued that it did not want to disclose the agreement to the Secretariat because, once released, anyone could access it under the Access to Information and Privacy $A_{c t^{18}}$ (October 6, 2015 telephone conversation, p. 25 of ATIP release).

Later, when the Secretariat suggested releasing only key parts of the agreement

${ }^{17} \mathrm{Kwantlen}$ is a repeat offender. In 2007, Ogden informed the Kwantlen administration that Kwantlen was violating its 2002 Memorandum of Understanding with SSHRC by failing to have created a scholarly integrity policy. Kwantlen did nothing to rectify that situation. In 2008, Kwantlen signed a second MOU with SSHRC when its administrators were well aware that it was violating it when it signed it. Consequently, Ogden made a formal complaint to SSHRC that Kwantlen had violated both its 2002 and 2008 MOUs with SSHRC, the agreements that made Kwantlen eligible to receive research funding.

On June 25, 2008, SSHRC wrote to Kwantlen President Skip Triplett directing Kwantlen to submit an integrity policy by March 31,2009, and arrange with an institution that had an approved integrity policy to oversee research at Kwantlen during the intervening period. SSHRC also directed Kwantlen to finish revising its research ethics policy by the same date to bring it into compliance with the TCPS. Failure to achieve these requirements would have resulted in SSHRC placing a hold on all Kwantlen SSHRC funds. Kwantlen satisfied the requirements, but it took a formal complaint and an SSHRC reprimand to secure compliance.

${ }^{18} \mathrm{https}: / /$ www.canada.ca/en/treasury-board-secretariat/services/access-information-privacy.html (accessed February 11, 2020). 
that would allow it to determine whether Ogden performed his research under Kwantlen's auspices, Kwantlen objected on the ground that it would not be possible to separate out the components relevant to that determination.

Neither argument holds water; both stretch credulity.

With regard to the first argument, Kwantlen gave a copy of the Confidential Agreement to Ogden's lawyer knowing that lawyer-client privilege protected it. Why did the Secretariat not emulate this strategy? It could have retained an attorney to whom Kwantlen could have sent a copy of the Agreement, knowing that lawyer-client privilege would shield it from an ATIP request. As to the second argument, what was Kwantlen's objection to the Secretariat seeing the whole Agreement if it could shield it from an ATIP request in the manner suggested?

Another suggestion the Secretariat might have made to Kwantlen was that the Kwantlen-Ogden arbitrator determine the matter of auspices using Kwantlen's research ethics policy AD093. However, the Secretariat did not suggest employing this rather obvious strategy.

\section{Keystone Cops}

The record of correspondence between the Secretariat and Kwantlen and the Secretariat's internal communications indicate that the Secretariat devoted a considerable amount of energy to the investigation in 2015 and 2016. Ultimately, however, theirs was the pursuit of failure. The funding agency Presidents rubber-stamping of this failure suggests that the Secretariat for Responsible Conduct of Research - and, in turn, the funding agency Presidents-are not capable of holding an institution like Kwantlen to account when it uses upwards of half-a-million dollars of tax-payer money to avoid its ethical and legal responsibilities under TCPS2.

Table 1 summarizes the Presidents' decision regarding each one of the seven allegations contained in the combined Lowman and Ogden complaints.

The Presidents' letter to Kwantlen President Alan Davis asserted that, because of the Confidential Agreement, the Secretariat, and in turn the three Presidents, were unable to reach any kind of conclusion regarding the first two complaints:

Without access to the relevant terms of this agreement, we are unable to determine whether the research was carried out under Kwantlen's auspices and are therefore unable to confirm or dismiss these allegations. We are therefore closing the file without a determination.

Without addressing any of my remaining five allegations, they then formally closed the file ${ }^{19}$.

\footnotetext{
${ }^{19}$ For "information purposes," the Presidents' letter also raised with Kwantlen two other issues. First, Article 4.4.e of the Responsible Conduct in Research Framework requires that institutions refrain from entering agreements that would prevent them from reporting to the Agencies through the Secretariat on matters involving agency funding-but with the caveat that the Kwantlen confidential agreement was created prior to the publication of the Framework Agreement and did not involve Agency funding. Second, if Ogden conducted the research under Kwantlen's auspices, TCPS2 Article 5.1 obliged Kwantlen to provide "financial and other support" to assist Ogden's defence of research-participant confidentiality in Coroner's Court. Further, the letter noted that the Secretariat has advised institutions to develop policies to explain the nature and scope of that support, a mechanism to determine the level of support in individual cases, the source of funding and any other relevant criteria.
} 
By way of conclusion I first address the Presidents' argument that they could not determine whether Ogden conducted his research from 2011-2015 under Kwantlen's auspices and, second, by discussing the implications of the allegations they ignored.

\subsection{Kwantlen Did Not Tell the Secretariat the Truth about the Confidential Agreement}

In an October 25, 2017 email to the Secretariat CEO, Ogden posed the following question:

If it is the case that the confidential agreement would exonerate Kwantlen from all aspects of Professor Lowman's complaint, why would Kwantlen refuse to release the confidential agreement to the Secretariat so that the complaint could be dismissed at the earliest point?

Following from this question and my earlier observations about the spurious nature of the reasons Kwantlen gave for not releasing it, if the Confidential Agreement established that Ogden did not do his 2011-2015 research under Kwantlen's auspices, why did he give permission for the Secretariat to see $\mathrm{it}^{20}$ ? Why did the Secretariat and the Presidents ignore this and other circumstantial evidence indicating that Kwantlen was not telling the truth, but Ogden was? For example, the documents released in response to Ogden's two ATIP requests illustrate beyond any reasonable doubt that Kwantlen paid Ogden's regular salary from 2011-2015, but that he had no teaching or administrative duties during that period. Indeed, Kwantlen banned him from attending any of its campuses. Ogden's only duty was "independent research." However, what determines whether Ogden conducted his research under Kwantlen's auspices or "independently" is its research ethics policy AD093, not the Confidential Agreement.

Kwantlen Policy AD093 holds that "Research conducted under the auspices of Kwantlen includes... research which utilizes Kwantlen resources (including accountable and professional development time)". Because Kwantlen used the public purse to pay Ogden's full-time salary to conduct "independent research"- -his only "assigned duty" during that period-clearly he conducted it under Kwantlen's auspices.

Insisting that a dandelion is a rose does not make it so.

\subsection{Why Did the Presidents Ignore Five of My Complaints?}

Then there is the matter of the five allegations of mine that the Funding-agency Presidents ignored (allegations 3 - 7 in Table 1, above). For clarity, I have numbered Ogden's two additional complaints in sequence with the five allegations I initially made in December 2014.

Allegation 3 held that the confidential agreement meant that Kwantlen vi-

${ }^{20} \mathrm{He}$ gave this permission on July 15, 2015 in his first correspondence to the Secretariat concerning Lowman's complaint. Although the Secretariat repeatedly asked Kwantlen for its permission, Kwantlen refused. 
olated Tri-Agency Framework Section 4.2, which holds that research institutions must "strive to provide an environment that ... fosters researchers' abilities to act honestly, accountably, openly and fairly in the search for, and dissemination of knowledge". Although the Tri-Agency Framework came into effect a couple of months after the confidential agreement was signed, once it did come into effect, surely Kwantlen needed to take some kind of action to ensure that Ogden's contact with prospective research participants satisfied this requirement-only that way could he be honest about his research and accountable to his research participants.

Further, TCPS2 was in effect when the three parties signed the confidential agreement. TCPS2 says that researchers must "provide participants with enough information to adequately assess risks and potential benefits associated with their participation in the research" (TCPS2 p.8). The Confidential Agreement prevented Ogden from complying with this requirement. Most importantly of all, however, is that in her March 13, 2015, letter to Kwantlen's lawyer, the Secretariat CEO said, “... we see this [section 4.2 breach] as subsidiary to the principal allegations of breach of the requirements of Articles 2.1 and 5.1 of TCPS2, although we would like Kwantlen to respond to that allegation as well' (emphasis added).

Why, then, did both the Secretariat and the three Agency Presidents subsequently ignore this allegation?

Allegation 4 asserted that Kwantlen did not comply with the requirement that the REB conduct an annual review of Ogden's research, assuming it was under Kwantlen's auspices. However, rather than arguing that it could make no determination of a breach, records disclosed in response to Ogden's ATIP request show that the Secretariat took the position that, because no research participant had come to harm, this was merely a "technical breach". This conclusion-yet another indication of the way the Secretariat appeared to be bending over backwards to let Kwantlen off the hook-was ethically irresponsible, as the history of third-party challenges to research confidentiality shows that many of these challenges occur long after the research has concluded. Although TCPS2 requires researchers to take a research-participant perspective, apparently that principle does not apply to the Secretariat that is supposed to ensure responsible conduct of research.

Allegation 5 asserted that Kwantlen did not honour Section 4.4.a.ii of the Agreement on the Administration of Agency Grants and Awards by Research Institutions, which says that an "institutional default" occurs "If the Institution has submitted materially false or misleading information or has made representations of a material nature to an Agency, other than in good faith".

On February 17, 2015, lawyers for Kwantlen informed the Secretariat that, "if Mr. Ogden believes the Confidential Agreement has been breached, then Mr. Ogden may use the dispute resolution mechanism contained in the Confidential Agreement to resolve that issue". On October 7, 2016, Kwantlen's attorney again 
suggested that Ogden could resort to the arbitration mechanism in the Confidential Agreement if he had an issue with Kwantlen's administration of that Agreement. There are two problems with this assertion. First, because the arbitration clause is part of the Confidential Agreement, Kwantlen violated confidentiality by disclosing it. Having disclosed this part of the Agreement because it suited Kwantlen's needs, its refusal to release the rest of the Agreement to the Secretariat was that much more egregious. Second, Ogden provided the Secretariat with conclusive evidence that Kwantlen was very well aware that this statement concerning the dispute resolution was not true. On November 14 2014, the arbitrator ruled that Ogden is not a party to the Confidential Agreement even though he signed it because, under the British Columbia Labour Relations Code, the faculty association has exclusive control over grievances.

On several occasions, Ogden requested that KFA file a request to clarify whether he was conducting his research under Kwantlen's auspices, but the KFA refused. In any event, because Kwantlen did not tell the truth about Ogden's access to the dispute mechanism and violated confidentiality in the process, Kwantlen was guilty of "institutional default". Why did the Secretariat and Funding Agency Presidents ignore this conspicuous instance of Kwantlen's bad faith?

Allegation 6 concerned the institutional conflict of interest that TCPS2 Chapter 7 section II prohibits, i.e. Ogden's submitting an annual report from 2011-2015 to the Kwantlen President rather than the REB. While the Secretariat wrote this off as a "technical breach" and therefore not worthy of penalty, both the Secretariat and the Presidents ignored the institutional conflict of interest involved in the Kwantlen administration being involved in ethics review. If the Presidents are not going to penalize an institution for acting on an institutional conflict of interest, why have the principle in the first place?

Allegation 7 concerned TCPS2 Article 1.1, which spells out the three "core principles" guiding TCPS2, i.e. respect for persons, concern for welfare and justice. From a participant perspective, the Confidential Agreement ensured confusion about the auspices under which Ogden conducted his research, particularly if a participant were to complain to Kwantlen about her or his rights.

This allegation brings us to the core of both my and Ogden's complaints. One does not need to know the auspices under which Ogden conducted his research to determine that the Confidential Agreement was itself an insult to the core ethical principles of TCPS2. Indeed, when initially considering my first complaint, an internal Secretariat memorandum dated January 9, 2015 made the following observation:

It seems inconsistent with the notion of concern for welfare to make confidential agreements that make it difficult for third parties to determine the auspices under which a research project is being conducted.

Had the Secretariat and the three funding agency Presidents focused on this 
inconsistency, they might have done justice to research participants across North America who put themselves at great risk by agreeing to participate in Ogden's research. Instead, by ignoring five of the seven allegations in the Lowman and Ogden complaints, and by ignoring the overwhelming circumstantial evidence that Ogden conducted his research under Kwantlen's auspices, again it appears that the Secretariat did everything it could to exonerate Kwantlen.

This case suggests that the Secretariat and Funding Agency Presidents either do not have the power or they do not have the motivation to hold research institutions to account when they blatantly ignore TCPS2 and other policies governing the ethical conduct of research in the way that Kwantlen has done. The Funding Agencies reluctance to hold Kwantlen to account suggests that it is time for the Agencies to chart a different course by establishing a research-confidentiality defence fund instead of requiring that individual institutions shoulder the burden of defending research confidentiality in court in order to protect the collective research enterprise. Either that or they have to find the courage to hold institutions like Kwantlen to account when they so egregiously disregard TCPS2 and other policies safeguarding human research participants in Canada.

\section{Conflicts of Interest}

The author declares no conflicts of interest regarding the publication of this paper.

\section{References}

Blomley, N., \& Davis, S. (1998). Russel Ogden Decision Review. http://www.sfu.ca/ palys/ogden.htm

CIHR (Canadian Institutes of Health Research), NSERC (Natural Sciences and Engineering Research Council), \& SSHRC (Social Sciences and Humanities Research Council) (2014). Tri-Council Policy Statement: Ethical Conduct for Research Involving $\mathrm{Hu}$ mans. Ottawa: Government of Canada.

Cribb, R. (2012) Death's Midwife Helps Terminally Ill Canadians End Their Lives. Toronto Star.

http://www.thestar.com/news/gta/2012/10/21/deaths_midwife_helps_terminally_ill_ca nadians end their lives.html

Lowman, J., \& Palys, T. S. (2001). Ethics and Institutional Conflict of Interest: The Research Confidentiality Controversy at Simon Fraser University. Sociological Practice, 2, 245-264. https://doi.org/10.1023/A:1026589415488

Lowman, J., \& Palys, T. S. (2014). The Betrayal of Research Confidentiality in British Sociology. Research Ethics, 10, 97-118. https://doi.org/10.1177/1747016113481145

Ogden, R. (1994). Euthanasia and Assisted Suicide in Persons Who Have Acquired Immunodeficiency Syndrome (AIDS) or Human Immunodeficiency Virus (HIV). MA Thesis, Simon Fraser University.

Ogden, R. (2014). Observing a Self-Chosen Death. In S. Fabian, M. Felices-Luna, \& J. Kilty (Eds.), Demarginalizing Voices: Commitment, Emotion, and Action in Qualitative Research (pp. 15-37). UBC Press.

Palys T. S., \& Lowman, J. (2014). Research Confidentiality: What Happens When Ethics 
and Law Collide. Lorimer (Published in the Canadian Association of University Teachers Academic Freedom Series).

Palys, T. S., \& Ivers, A. (2018). Hope for the Best, Plan for the Worst: Understanding Administrative Inertia in Developing Confidentiality Protection Policies. Journal of Empirical Research on Human Research Ethics, 13, 438-451. https://doi.org/10.1177/1556264618789246

Palys, T. S., \& Lowman, J. (2010). Going Boldly Where No One Has Gone Before: How Confidentiality Risk Aversion Is Killing Research on Sensitive Topics. Journal of Academic Ethics, 8, 265-284. https://doi.org/10.1007/s10805-010-9113-0

Palys, T. S., \& Lowman, J. (2019). Eight Challenges to Research Confidentiality in Canada: Invoking and Protecting Research-Participant Privilege. In C. Hunt (Ed.), The Law of Privilege in Canada. Thomson Reuters.

Palys, T. S., Turk, J. L., \& Lowman, J. (2018). Statute-Based Protections for Research Participant Confidentiality: Implications of the US Experience for Canada. Canadian Journal of Law and Society, 33, 1-20. https://doi.org/10.1017/cls.2018.24

Wigmore, J. H. (1905). A Treatise on the System of Evidence in Trials at Common Law, Including the Statutes and Judicial Decisions of All Jurisdictions of the United States, England, and Canada. Little, Brown and Company. 